\title{
PELATIHAN PUBLIKASI KARYA ILMIAH BAGI GURU SMK AL-INABAH KECAMATAN BABADAN KABUPATEN PONOROGO
}

\author{
Mohammad Arfi Setiawan $^{1 *}$, Ade Trisnawati \\ ${ }^{1 *}$ Program Studi Teknik Kimia, Universitas PGRI Madiun. \\ 2Program Studi Teknik Kimia, Universitas PGRI Madiun. \\ ${ }^{*}$ Corresponding author : \\ E-mail : marfis@yahoo.com
}

Diterima 2 November 2018, Disetujui 7 November 2018

\begin{abstract}
ABSTRAK
Publikasi merupakan tahap akhir yang penting dilakukan dalam penulisan karya ilmiah. Publikasi adalah cara yang dilakukan agar karya atau hasil temuan dapat dikenal secara luas, sehingga dapat menambah dan mengembangkan ilmu pengetahuan. Guru dituntut tidak hanya mengajar tetapi juga menghasilkan karya atau temuan. Salah satu bentuk pengembangan profesi guru adalah pengembangan kemampuan guru dalam membuat karya tulis ilmiah. Kemampuan ini dapat dilihat dari publikasi para guru yang dimuat dalam berbagai media, khususnya jurnal ilmiah. Namun sebagian besar guru tidak mau menyusun dan melakukan publikasi karena membutuhkan waktu dan tenaga, sehingga guru hanya menyusun karya ilmiah tanpa melakukan publikasi. Program ini berupa sosialisasi mengenai publikasi karya ilmiah dimaksudkan untuk memberi pengetahuan dan memotivasi guru agar melakukan publikasi karya ilmiah ke dalam jurnal. Selain itu, dilakukan juga pelatihan publikasi karya ilmiah ke dalam jurnal sehingga dapat dilakukan sendiri oleh guru-guru khususnya guru SMK Al-Inabah. Hasil kegiatan ini yaitu pengetahuan guru tentang publikasi artikel makin meningkat.
\end{abstract}

Kata kunci: artikel, karya ilmiah, pelatihan jurnal, publikasi

\begin{abstract}
Publication is the final stage that important to do in writing scientific papers. Publication is a way for work or findings can be widely known, so that it can add and develop knowledge. Teachers are required not only to teach but also to produce work or findings. One form of professional teacher development is the development of the teacher's ability to make scientific papers. This ability can be seen from the publications of teachers that published in various media, especially scientific journals. But most teachers do not want to compile and publish because it requires time and energy, so the teacher only prepares scientific paper without publication. This program in the form of socialization about publication of scientific papers is intended to provide knowledge and motivate teachers to publish scientific papers into journals. In addition, training was also carried out in the publication of scientific papers in journals so that teachers could be carried out alone, especially teacher of Al-Inabah Vocational High Schools. The result of activity is the teacher's knowledge of article publication is increasing.
\end{abstract}

Keywords: article, journal training, publication, scientific papers

\section{PENDAHULUAN}

Bagi para akademisi, publikasi karya ilmiah bukan hanya sebagai prasyarat, tapi juga demi masa depan bangsa. Seperti yang dikatakan oleh Widodo dalam seminarnya di UNY (2013),

"Kalau hasil penelitian hanya disimpan

di perpustakaan, siapa yang berminat untuk membacanya? Apalagi dengan tebalnya halaman yang ada. Bisa-bisa, mau membaca saja malas,".

Semua orang yang memiliki karya/ temuan hendaknya melakukan publikasi tidak terkecuali profesi seorang guru. Guru dituntut tidak hanya mengajar tetapi juga menghasilkan karya atau temuan. Salah satu bentuk pengembangan profesi guru adalah pengembangan kemampuan guru dalam membuat karya tulis ilmiah. Kemampuan ini dapat dilihat dari publikasi para guru yang dimuat dalam berbagai media, khususnya jurnal ilmiah.

Kemampuan guru dalam menulis karya ilmiah dan menerbitkannya di jurnal ilmiah adalah salah satu upaya untuk mendapatkan angka kredit sebagai persyaratan peningkatan karir atau kenaikan pangkat. Berdasarkan Peraturan Menteri Pendidikan Nasional nomor 35 tahun 2010, guru diwajibkan melakukan publikasi karya ilmiah untuk melakukan pengajuan kenaikan 
pangkat. Namun kenyataan menunjukkan banyak guru yang stagnan atau berhenti di golongan IVa karena untuk naik ke jenjang golongan IVb mereka harus menulis karya ilmiah dan publikasi.

Sebagian besar guru tidak mau menyusun dan melakukan publikasi karena membutuhkan waktu dan tenaga, sehingga guru hanya menyusun karya ilmiah tanpa melakukan publikasi. Menyusun karya ilmiah membutuhkan waktu, tenaga pikiran dan fisik yang ekstra, mulai dari membaca referensi sebanyak mungkin sampai dengan menulis. Hal tersebut dilakukan agar dihasilkan kaya ilmiah yang komprehensif dan mendalam. Sedangkan publikasi harus menyesuaikan dengan media yang akan memuat karya ilmiah sehingga perlu adanya editing dan menyesuaikan dengan saran dari editor serta harus memperhatikan plagiasi. Hal tersebut yang ada dimindset sebagian besar guru yang menyebabkan kurangnya motivasi guru sehingga banyak karya ilmiah dari guru yang tidak disebarkan secara luas (publikasi). Kondisi ini terjadi di salah satu sekolah di Kecamatan Babadan Kabupaten Ponorogo yaitu SMK AlInabah, sehingga perlu dilakukan perubahan mindset guru dalam memahami publikasi suatu karya ilmiah.

Sosialisasi dan pelatihan bagi guru hanya pada tataran penulisan karya ilmiah dan tidak sampai melakukan publikasinya. Seperti yang dilakukan oleh Aina dkk (2015) yaitu melakukan pelatihan penulisan karya ilmiah bagi guru SMA 8 kota Jambi; Aisyah dan Mahanani (2017) melakukan pelatihan penulisan artikel ilmiah bagi guru-guru SD dan TK di Kecamatan Tajinan Kabupaten Malang; Ilfiandra dkk (2016) melakukan pelatihan dan pendampingan penulisan karya ilmiah bagi guru SD. Pengetahuan guru yang tidak tahu tentang publikasi karya ilmiah menyebabkan artikel-artikel yang sudah baik tidak terbit dalam jurnal, sehingga diperlukan sosialisasi dan pelatihan publikasi karya ilmiah.

\section{METODE PELAKSANAAN}

Tahapan pelaksanaan kegiatan pengabdian ini meliputi: 1) Koordinasi dengan mitra, terkait dengan penyusunan jadwal kegiatan; 2) Persiapan sosialisasi dan pelatihan; 3) Sosialisasi tentang publikasi karya ilmiah melalui jurnal; dan 4) Pelatihan publikasi karya ilmiah melalui jurnal.

Kegiatan yang dilakukan dalam program kemitraan masyarakat ini secara garis besar adalah sebagai berikut:

1. Sosialisasi

Tujuan sosialisasi ini adalah memberikan ilmu dan wawasan baru kepada guru tentang publikasi karya ilmiah melalui jurnal, sehingga dapat meningkatkan minat guru dalam melakukan publikasi karya ilmiah yang dihasilkan melalui jurnal. Disamping itu, juga diberikan tips memilih jurnal yang akan dijadikan media publikasi. Sosialisasi ini disampaikan dalam bentuk ceramah dan tanya jawab kepada peserta.

2. Pelatihan

Kegiatan ini bertujuan untuk memberikan keterampilan tentang cara publikasi karya ilmiah melalui jurnal. Pelatihan tersebut disampaikan dalam bentuk ceramah yang dilanjutkan dengan eksperimen langsung dan tanya jawab tentang cara publikasi karya ilmiah. Guru dilatih melakukan submit karya ilmiah/artikel ke dalam jurnal yang telah dipilih.

\section{HASIL DAN PEMBAHASAN \\ Sosialisasi dan Pelatihan Publikasi Artikel IImiah}

Pengabdian masyarakat dengan tema pelatihan publikasi artikel ilmiah dilaksanakan pada hari sabtu tanggal 28 April 2018. Sasaran dari program ini adalah guru SMK Al-Inabah Kecamatan Babadan Kabupaten Ponorogo. Sebelum pelaksanaan pengabdian, tim berkoordinasi dengan pihak-pihak terkait tentang tempat dan waktu pelaksanaan. Program pengabdian masyarakat dimulai dengan pendaftaran peserta, kemudian dilanjutkan sosialisasi dan pelatihan dari tim pengabdian masyarakat. Kegiatan sosialisasi publikasi dari tim dapat dilihat pada Gambar 1.

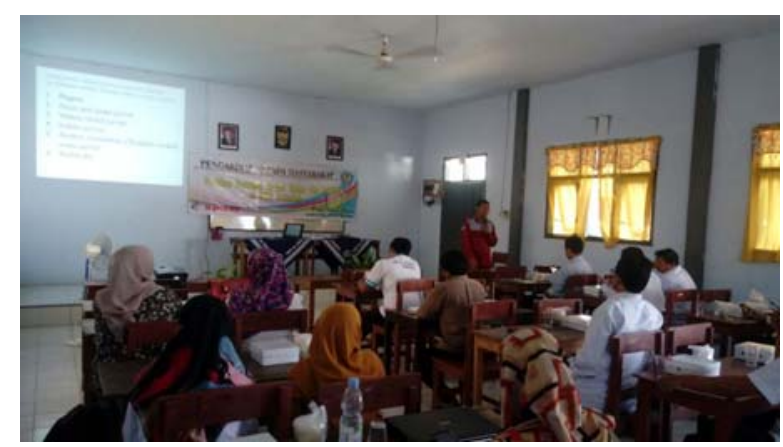

Gambar 1. Sosialisasi Publikasi Karya IImiah

Rencana awal, peserta hanya guru dari SMK Al-Inabah saja, tetapi guru-guru dari luar SMK juga ikut dalam pelatihan karena tingginya minat, sehingga peserta pelatihan adalah guruguru SMK Al-Inabah dan guru dari luar SMK. Acara ini berjalan dengan lancar hal ini terbukti banyaknya antusiasme dari guru-guru yang mengikuti sosialisasi program pengabdian masyarakat berupa pelatihan publikasi artikel ilmiah.

Kegiatan ini dimulai dengan sambutan kepala sekolah SMK Al-Inabah. Pada awal 
kegiatan tim sosialisasi menjelaskan tentang publikasi karya ilmiah dalam jurnal. Pemateri menyampaikan hal-hal yang perlu diperhatikan dalam melakukan publikasi yaitu plagiasi dan autoplagiasi, serta tata cara penulisan artikel (template). Selain itu, disampaikan juga tata cara memilih jurnal yang cocok untuk media terbitan artikel. Hal-hal yang perlu diperhatikan dalam memilih jurnal yaitu, focus and scope, waktu terbit, indeksasi, biaya penerbitan dan template artikel. Pelatihan publikasi dilakukan dengan menjelaskan tata cara submit artikel, sampai dengan proses revisi. Setelah sosialisasi dan pelatihan dilakukan pendampingan yang dilakukan kepada guru diluar jam pelatihan. Pendampingan guru dapat dilihat pada Gambar 2.

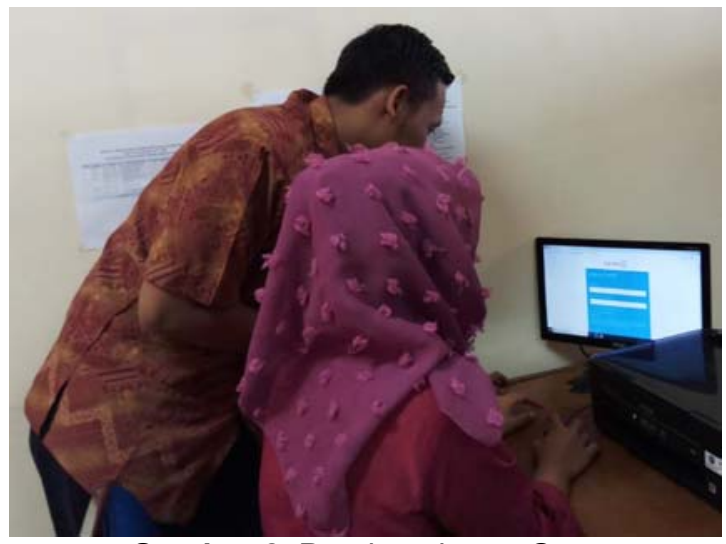

Gambar 2. Pendampingan Guru

\section{Materi Sosialisai dan Pelatihan}

Tata Cara Publikasi dalam Jurnal

Sistem publikasi melalui jurnal sudah berpindah dari cetak menjadi online sehingga publikasi lebih mudah yaitu dengan melakukan submit artikel. Namun ada beberapa yang perlu diperhatikan sebelum submit artikel antara lain,

1. Focus and Scope

Focus and scope merupakan topiktopik artikel yang dapat dipublikasikan pada suatu jurnal. Hal ini sangat perlu diperhatikan karena seleksi awal dari pengelola jurnal adalah keterkaitan artikel dengan focus and scope jurnal.

\section{Indeksasi Jurnal}

Indeks merupakan alat yang digunakan online atau dalam dunia Internet, oleh para peneliti dan pustakawan untuk menemukan konten ilmiah. Semakin banyak indeks dari sebuah jurnal akan semakin baik. Ada beberapa indeks jurnal yang baik seperti DOAJ dan SCOPUS.

3. Author Guidelines

Panduan penulis (author guidelines) merupakan penjelasan mengenai submit jurnal dan format (template) artikel yang diinginkan. Penulis harus memperhatikan template agar artikel tidak terlalu banyak revisi nantinya.

\section{Author fee}

Biaya penerbitan juga perlu diperhatikan dalam pemilihan jurnal. Makin banyak indeks dan makin bagus dalam sebuah jurnal biasanya diperlukan biaya yang cukup banyak.

\section{Waktu terbit}

Jurnal minimal dua nomer dalam satu volume dan maksimal empat nomor dalam satu volume. Makin banyak nomor dalam satu volume dapat dikatakan mustahil dalam sebuah penerbitan jurnal dan dapat disimpulkan jurnal tersebut kurang bagus. Selain itu, waktu terbit juga digunakan untuk estimasi penerbitan oleh penulis.

Setelah menemukan jurnal yang sesuai, selanjutnya karya ilmiah yang berupa artikel ditulis sesuai template jurnal dan disubmit. Artikel tidak langsung diterbitkan tetapi masih perlu adanya review dan revisi.

\section{Evaluasi dan Tindak Lanjut}

Evaluasi kegiatan dilakukan dengan tanya jawab kepada guru-guru peserta pelatihan untuk melihat sejauh mana tanggapan peserta terhadap kegiatan yang telah dilakukan. Aspek yang ditinjau adalah tentang pendapat dan tanggapan peserta tentang pelaksanaan pelatihan publikasi karya ilmiah dalam jurnal. Berdasarkan pertanyaan dari guru diketahui, sebagian besar guru belum memahami tentang maksud plagiasi dalam jurnal serta beda antara plagiasi dan selfplagiasi/autoplagiasi. Selain itu, guru juga belum memahami indeksasi jurnal.

Hasil diskusi memperlihatkan bahwa mitra sangat setuju dengan kegiatan pengabdian ini karena dengan adanya sosialisasi dan pelatihan tentang publikasi karya ilmiah dalam jurnal peserta jadi tahu seputar jurnal dan cara publikasinya. Selain itu, materi yang disampaikan mudah dimengerti dan mudah dipraktekan sendiri, waktu pelaksanaan kegiatan tidak mengganggu kegiatan belajar mengajar karena dilaksanakan ketika siswa telah selesai melakukan ujian. Disamping itu peserta juga termotivasi dan tertarik untuk melakukan publikasi karya ilmiah dalam jurnal.

Pelatihan dan pendampingan guru mengenai karya ilmiah memang diperlukan untuk memberikan wawasan dan motivasi kepada guru. Program pelatihan dan pendampingan merupakan pelaksanaan program strategis untuk memberikan layanan pengembangan kompetensi guru. Selain itu, kegiatan ini merupakan kepanjangan tangan untuk mensosialisasikan ragam kegiatan 
pengembangan profesi kepada para guru di lapangan (Ilfiandra dkk., 2016)

\section{SIMPULAN}

Kegiatan kemitraan masyarakat terlaksana sesuai dengan rencana. Pengetahuan guru tentang publikasi karya ilmiah dalam jurnal makin bertambah. Guru-guru peserta pelatihan termotivasi untuk melakukan publikasi dalam jurnal ilmiah.

\section{UCAPAN TERIMA KASIH}

Ucapan terima kasih kami sampaikan kepada Universitas PGRI Madiun yang teah memberikan bantuan dana demi kelangsungan pengabdian masyarkat ini.

\section{DAFTAR RUJUKAN}

Aina, M., Bambang, H., Retni, S. B., Afreni, H., \& Sadikin, A., "Pelatihan penulisan karya tulis ilmiah bagi guru SMA 8 kota Jambi", Jurnal Pengabdian pada Masyarakat. Vol 30, No. 3, h. 29-32. 2015.

Aisyah, E. N., \& Mahanani, P., "Pelatihan menuliskan artikel ilmiah bagi guru Sekolah Dasar dan Taman Kanakkanak Kecamatan Tajinan Kabupaten Malang", ABDIMAS PEDAGOGI, Vol. 1, No. 1, h. 2-26, 2017.

Ilfiandra, Suherman, U., Akhmad, S. N., Budiamin, A., \& Setiawati, "Pelatihan dan pendampingan penulisan karya tulis ilmiah bagi guru SD", Jurnal Pengabdian pada Masyarakat, Vol. 1, No. 1, h. 70-81, 2016.

Peraturan Menteri Pendidikan Nasional. 2010. Petunjuk Teknis Pelaksanaan Jabatan Fungsional Guru Dan Angka Kreditnya. Salinan Lampiran. http://jatim.kemenag.go.id/file/file/perat urantentangPNS/tiwo1413864390.pdf

Widodo, P. 2013. Pentingnya Publikasi Karya IImiah. Dikutip dari berita yang ditulis oleh Nurhadi. https://www.uny.ac.id/?q=berita/pentin gnya-publikasi-karya-ilmiah.html 